Article

\title{
Synthesis and Pharmacological Activity of Diterpenylnaphthoquinone Derivatives
}

\author{
Mariano Walter Pertino ${ }^{1}$, Cristina Theoduloz ${ }^{2}$, Jose Antonio Palenzuela ${ }^{3}$, \\ Maria del Mar Afonso ${ }^{3}$, Erdem Yesilada ${ }^{4}$, Francisco Monsalve ${ }^{2}$, Paulo González ${ }^{2}$, \\ Daniel Droguett ${ }^{2}$ and Guillermo Schmeda-Hirschmann ${ }^{1, *}$ \\ 1 Instituto de Química de Recursos Naturales, Universidad de Talca, Casilla 747, Talca, Chile \\ 2 Facultad de Ciencias de la Salud, Universidad de Talca, Casilla 747, Talca, Chile \\ 3 Instituto Universitario de Bio-Orgánica Antonio Gonzalez G., Universidad de La Laguna, \\ Tenerife 38206, Spain \\ 4 Faculty of Pharmacy, Yeditepe University, Istanbul 34755, Turkey \\ * Author to whom correspondence should be addressed; E-Mail: schmeda@utalca.cl; \\ Tel.: +56-71-200288; Fax: + 56-71-201573.
}

Received: 13 September 2011; in revised form: 29 September 2011 / Accepted: 30 September 2011 / Published: 13 October 2011

\begin{abstract}
New diterpenylquinones, combining a diterpene diacid and a naphthoquinone, were prepared from junicedric acid and lapachol. The new derivatives were assessed as gastroprotective agents by the $\mathrm{HCl}-\mathrm{EtOH}$-induced gastric lesions model in mice as well as for basal cytotoxicity on the following human cell lines: Normal lung fibroblasts (MRC-5), gastric epithelial adenocarcinoma (AGS), and hepatocellular carcinoma (Hep G2). Several of the new compounds were significantly active as antiulcer agents and showed selective cytotoxicity against AGS cells.
\end{abstract}

Keywords: labdane diterpenes; lapachol derivatives; diterpenylnaphthoquinones; gastroprotection; basal cytotoxicity

\section{Introduction}

In the year 2002 stomach cancer and peptic ulcer disease represented 1.5 and $0.5 \%$ of the total causes of death worldwide, respectively [1]. Chronic gastric ulcers can lead to gastric and pancreatic cancer $[2,3]$. Several natural products have been shown to display significant gastroprotective effects 
in animal models of induced gastric ulcers. These agents include diterpenes with different structural skeletons [4-11]. The labdane diterpenes from Araucaria araucana (Molina) Koch (Araucariaceae) and their semisynthetic derivatives present gastroprotective activity with a wide range of basal cytotoxicity on human cell lines [9,10]. According to Halle and Spielmann there is a significant correlation between cytotoxicity of mammalian cell culture systems and acute oral toxicity $\left(\mathrm{LD}_{50}\right)$ in animals [12]. Basal cytotoxicity is a valid model to predict starting doses for in vivo lethality assays in rodents.

Lapachol is a naphthoquinone that can be obtained in high yields from the wood or trunk bark of Tabebuia species (Bignoniaceae), including Tabebuia heptaphylla (Vell. Conc.) Toledo [13]. Several bioactivities have been described for lapachol and its semisynthetic derivatives, e.g., activation of the Epstein-Barr virus [14], molluscicidal [15,16], trypanocidal [17], antiviral, antiproliferative [18], and DNA-topoisomerase inhibitory activity [19].

A new approach to drug design is to link two molecules with individual intrinsic effect into a single compound, named a "hybrid compound" [20]. A classification of "hybrid" molecules includes conjugates, cleavage conjugates, fused hybrid molecules, and merged hybrids [20-23]. The use of lapachol to obtain lapachol hybrid derivatives with diterpenes has not been explored previously, but changes in the gastroprotective effect and basal cytotoxicity of the resulting products should be expected.

In this paper we describe the preparation of junicedric acid and lapachol derivatives and examine the structure-activity relationships/trends of the new compounds as gastroprotective agents in mice. The basal cytotoxicity of the new compounds was also assessed towards the following human cell lines: normal lung fibroblasts (MRC-5), epithelial adenocarcinoma (AGS), and hepatocellular carcinoma (Hep G2).

\section{Results and Discussion}

The diterpene junicedric acid (I) (Scheme 1) was obtained by saponification and oxidation of a mixture of labdane diterpenes from Araucaria araucana [9,10]. Isomerization of the double bond of $\mathbf{I}$ to II was carried out by treating $\mathbf{I}$ in acetic acid (HOAc) with $\mathrm{HBr}$. Reduction of the double bond of $\mathbf{I}$ was carried out by catalytic hydrogenation of the terpene (Scheme 1). Lapachol (2-hydroxy-3-(3methyl-2-butenyl)-[1,4]-naphthoquinone) (IV, Scheme 2) was obtained from "lapacho" wood extract [13]. The hydrogenated products were obtained treating lapachol in ethyl acetate (EtOAc) with palladium on activated carbon $(\mathrm{Pd} / \mathrm{C})$ (Scheme 2$)$.

Scheme 1. Preparation of derivatives II and III from junicedric acid (I).

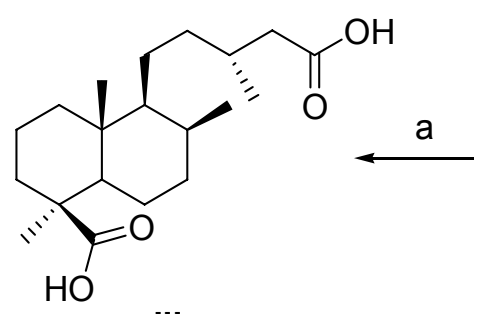

III

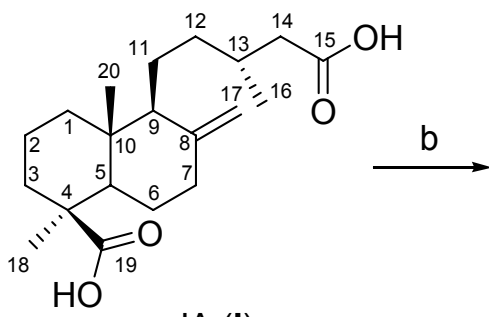

JA (I)

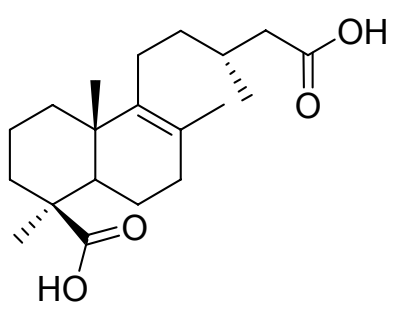

II

Reagents and conditions: (a) $\mathrm{H}_{2}, \mathrm{Pd} / \mathrm{C} 10 \%$, rt, EtOAc; (b) HOAc/HBr, rt, $24 \mathrm{~h}$. 
Scheme 2. Preparation of derivatives V and VI from lapachol (IV).<smiles>CC(C)=CC=CC(C)=CC1=C(O)C(=O)c2cc[c]cc2C1=O</smiles>

Reagents and conditions: (a) $\mathrm{H}_{2}, \mathrm{Pd} / \mathrm{C} 10 \%$, EtOAc, rt; (b) $\mathrm{H}_{2}, \mathrm{Pd} / \mathrm{C} 10 \%, 4$ bar, 2 h, $65{ }^{\circ} \mathrm{C}$, HOAc.

Twelve esters combining a diterpene and lapachol or its derivatives were prepared in moderate to good yields starting from the diterpene diacids I, II or III. The quinone moieties used included 2-hydroxy-3-(3-methyl-2-butenyl)-[1,4]-naphthoquinone (lapachol) (IV), 2-hydroxy-3-(3-methylbutyl)-[1,4]-naphthoquinone (V) (dihydroprenyllapachol) and 2-hydroxy-3-(3-methyl-butyl)-5,6,7,8tetrahydro-[1,4]-naphthoquinone (VI) (dihydroprenyl-5,6,7,8-tetrahydrolapachol) (Scheme 2). All the products were characterized by spectroscopic means. Compounds 1-12 (Figure 1) are described for the first time.

Figure 1. Structures of compounds 1-12.

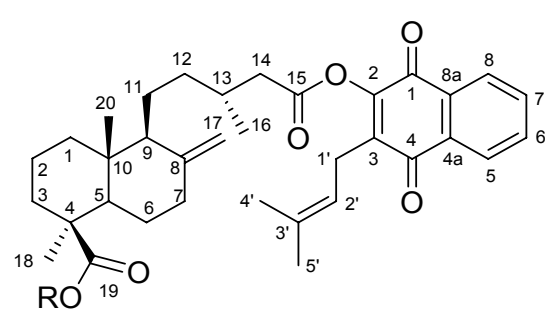

1: $\mathrm{R}=\mathrm{H}$
2: $\mathrm{R}=\mathrm{CH}_{3}$

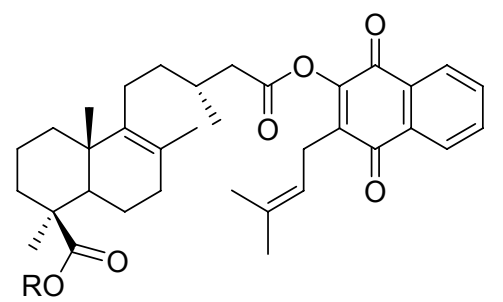

7: $\mathrm{R}=\mathrm{H}$;

8: $\mathrm{R}=\mathrm{CH}_{3}$

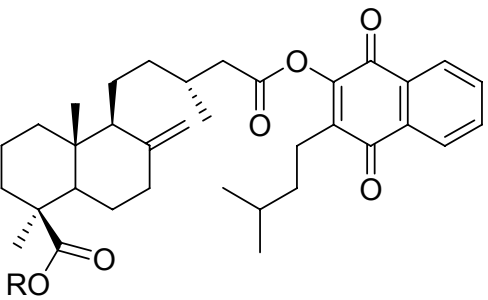

3: $\mathrm{R}=\mathrm{H}$;

4: $\mathrm{R}=\mathrm{CH}_{3}$<smiles>[R20]C(=O)[C@H]1CCCC2=C(C)CC[C@H](CC(=O)OC3=C(CCC(C)C)C(=O)c4ccccc4C3=O)CC[C@@]21C</smiles>

9: $\mathrm{R}=\mathrm{H}$;

10: $\mathrm{R}=\mathrm{CH}_{3}$

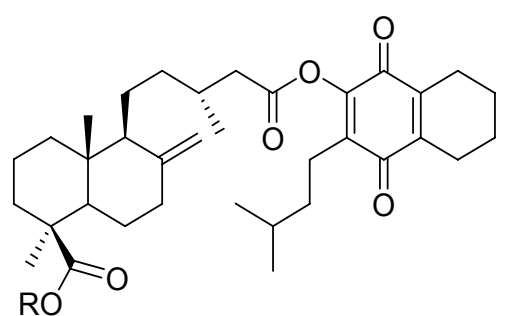

5: $\mathrm{R}=\mathrm{H}$;

6: $\mathrm{R}=\mathrm{CH}_{3}$

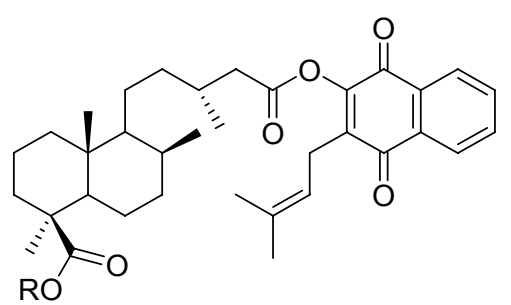

11: $\mathrm{R}=\mathrm{H}$;

12: $\mathrm{R}=\mathrm{CH}_{3}$

The diterpene junicedric acid has two acid groups at C-15 and C-19. However, only the acid group at $\mathrm{C}$-15 is reactive enough to form esters or amides when the diacid is treated with $N, N$-dicyclohexylcarbodiimide (DCC)/dimethylaminopyridine (DMAP) and the alcohols or amines. Diesters or diamides can be obtained via the acyl chloride [24].

Compounds 1-12 were evaluated for gastroprotective effect and basal cytotoxicity (Tables 1 and 2).

When assayed for gastroprotective effect, lapachol (IV) at 5, 10 and $50 \mathrm{mg} / \mathrm{kg}$ did not present a statistically significant effect in the EtOH-HCl-induced gastric lesions model in mice when compared with the vehicle control (Tween 80). Comparisons were made using Dunnett's or Student-Newman- 
Keuls test (data not shown). Compound II reduced gastric lesions by $79 \%$ at $5 \mathrm{mg} / \mathrm{kg}$. The diterpenelapachol hybrid derivatives were investigated for gastroprotective effect at a single oral dose of $5 \mathrm{mg} / \mathrm{kg}$ (Table 1).

Table 1. Gastroprotective effect of compounds 1-12 on the HCl-EtOH-induced gastric lesion model in mice. All compounds were assessed at a single oral dose of $5 \mathrm{mg} / \mathrm{kg}$.

\begin{tabular}{lccc}
\hline Compound & $\begin{array}{c}\text { Lesion index }(\mathbf{m m}) \\
\text { Mean } \pm \text { SEM }\end{array}$ & Protection (\%) & Protected stomachs ${ }^{\mathbf{a}}$ \\
\hline Tween & $27.2 \pm 9.3$ & & \\
$\Delta 8(9)$ junicedric acid (II) & $5.3 \pm 2.4 *$ & 79 & $4 / 9$ \\
$\mathbf{1}$ & $15.3 \pm 5.0$ & 44 & $1 / 14$ \\
Tween & $25.0 \pm 6.9$ & & $4 / 9$ \\
$\mathbf{2}$ & $8.7 \pm 3.9$ & 65 & $0 / 9$ \\
$\mathbf{5}$ & $20.4 \pm 3.6$ & 18 & $3 / 8$ \\
$\mathbf{6}$ & $6.5 \pm 2.7 *$ & 74 & $1 / 8$ \\
$\mathbf{7}$ & $11.5 \pm 4.4$ & 54 & $5 / 9$ \\
$\mathbf{8}$ & $3.9 \pm 1.9 *$ & 84 & $0 / 10$ \\
$\mathbf{1 1}$ & $23.5 \pm 3.6$ & 6 & $0 / 7$ \\
$\mathbf{1 2}$ & $27.4 \pm 6.8$ & - & $0 / 9$ \\
Tween & $43.3 \pm 8.2$ & & $0 / 8$ \\
$\mathbf{3}$ & $17.9 \pm 4.6 * *$ & 59 & $0 / 9$ \\
$\mathbf{4}$ & $19.3 \pm 5.0 * *$ & 55 & $0 / 9$ \\
$\mathbf{9}$ & $15.7 \pm 4.5 * *$ & 64 & $3 / 9$ \\
$\mathbf{1 0}$ & $10.2 \pm 3.5 * *$ & 76 & $6 / 9$ \\
Lansoprazole $(20 \mathrm{mg} / \mathrm{kg})$ & $9.4 \pm 1.2 * *$ & 73 & \\
\hline$*$ and $* *: P<0.05$ different from untreated control (Tween); ${ }^{\mathrm{a}}$ Number of stomachs which were \\
completely protected from any visible bleeding. One-way ANOVA with Student-Newman-Keuls \\
post-hoc test. & & &
\end{tabular}

Derivatives 6 and 8 were significantly active, protecting 3/8 and 5/9 animals, respectively, from lesions or stomach bleeding. An important gastroprotective effect was seen with derivatives 3, 4, 9 and 10 compared to untreated controls. However, for compounds 3, 4 and 9 all the stomachs showed at least some lesions or bleeding. Compound $\mathbf{1 0}$ was a very active gastroprotective agent. Compounds $\mathbf{8}$ and $\mathbf{1 0}$ are methyl esters of II and IV, the quinone moiety bearing either the prenyl side chain or the reduced prenyl side chain. Compound $\mathbf{6}$ was built from I and VI. It showed very low basal cytotoxicity $(>1 \mathrm{mM})$ and proved to be one of the best gastroprotective products found in this study. The most active compounds are $\mathrm{C} 19$ methyl esters of the parent compounds. This fact shows that changes in the structure of any of the moieties will lead to changes in activity of the new compounds.

The diterpenylnaphthoquinones as well as I, II and IV were evaluated for basal cytotoxicity using MRC-5 fibroblasts, AGS and Hep G2 cells (Table 2). No significant differences in basal cytotoxicity were found between derivatives 1 and 7 , where the diterpene moiety presents the double bond either at 8(17)-en- (compound 1) or at 8(9)-en- (compound 7). 
Table 2. Basal cytotoxicity of the lapachoyl ester derivatives from labdane diterpenes 1-12 towards MRC-5 fibroblasts and AGS and Hep G2 cells.

\begin{tabular}{cccc}
\hline \multirow{2}{*}{ Compound } & \multicolumn{3}{c}{ IC $_{\mathbf{5 0}} \pm \mathbf{S E M}^{\mathbf{a}}(\boldsymbol{\mu M})$} \\
\cline { 2 - 4 } & Fibroblasts & AGS & Hep G2 \\
\hline Lapachol (IV) & $>1000$ & $382 \pm 15$ & $55 \pm 3$ \\
Junicedric acid (I) & $181 \pm 9$ & $304 \pm 18$ & $>1000$ \\
$\Delta 8(9)$ junicedric acid (II) & $214 \pm 32$ & $343 \pm 22$ & $>1000$ \\
$\mathbf{1}$ & $210 \pm 13$ & $170 \pm 9$ & $57.4 \pm 4.4$ \\
$\mathbf{2}$ & $741 \pm 40$ & $361 \pm 19$ & $208 \pm 11$ \\
$\mathbf{3}$ & $156 \pm 9$ & $89 \pm 5$ & $>1000$ \\
$\mathbf{4}$ & $>1000$ & $382 \pm 26$ & $>1000$ \\
$\mathbf{5}$ & $69 \pm 3$ & $40 \pm 6$ & $27 \pm 1$ \\
$\mathbf{6}$ & $>1000$ & $>1000$ & $>1000$ \\
$\mathbf{7}$ & $190 \pm 8$ & $179 \pm 9$ & $96 \pm 9$ \\
$\mathbf{8}$ & $>1000$ & $721 \pm 35$ & $379 \pm 21$ \\
$\mathbf{9}$ & $341 \pm 17$ & $294 \pm 15$ & $>1000$ \\
$\mathbf{1 0}$ & $>1000$ & $162 \pm 10$ & $>1000$ \\
$\mathbf{1 1}$ & $336 \pm 15$ & $114 \pm 7$ & $54.5 \pm 5$ \\
$\mathbf{1 2}$ & $926 \pm 35$ & $323 \pm 16$ & $290 \pm 9$ \\
Etoposide & $0.33 \pm 0.02$ & $0.58 \pm 0.02$ & - \\
Lansoprazole $^{\mathrm{b}}$ & $306 \pm 11$ & $162 \pm 6$ & $221 \pm 9$ \\
\hline
\end{tabular}

a Confluent cultures were treated with the culture medium containing the compounds at concentrations ranging between 0 and $1,000 \mu \mathrm{M}$ for $24 \mathrm{~h}$. Cell viability was determined by the neutral red uptake assay. Data are expressed as arithmetic mean values of three different experiments in quadruplicate $\pm \mathrm{SEM} ;{ }^{\mathrm{b}}$ Reference compound.

Cytotoxicity strongly decreases after methylation, showing the relevance of the $\mathrm{COOH}$ function at C-19 for this effect. In a broad sense, all compounds displayed lower basal cytotoxicity against fibroblasts than against AGS or Hep G2 cells. Some selectivity was seen for compounds 1, 5, 7 and 11 towards Hep G2 cells. The most cytotoxic compound of this series (5) was built with I and the hydrogenation product of lapachol VI. The $\mathrm{IC}_{50}$ values of this compound towards fibroblasts, AGS and Hep G2 cells were 69, 40 and $27 \mu \mathrm{M}$, respectively. The increase in cytotoxicity was associated with poor selectivity. The effect is completely lost after methylation of the $\mathrm{C}-19 \mathrm{COOH}$ function of the diterpene.

A similar approach, but starting from myrcecommunic acid and $p$-benzoquinone was used to prepare new diterpenylnaphthoquinones through a Diels-Alder cycloaddition [25]. Several of the diterpenylnaphthoquinones presented higher cytotoxicity than the quinone moiety itself, the naphthoquinone (NQ) system showing better effect than benzoquinone or anthraquinone derivatives $[25,26]$. The most promising compounds present variations in the decaline part of the naphthohydroquinone (NHQ) of the NQ system and show $\mathrm{GI}_{50}$ values (growth inhibition values that reduce cell growth by $50 \%$ ) in the $0.12-0.50 \mu \mathrm{M}$ range towards the tumour cell lines A-549 (lung carcinoma), HT-29 (colon carcinoma), and MEL-28 (malignant melanoma) [25]. The main difference with this report is that [25] formed $\mathrm{C}$-C bonds by cycloaddition, while we prepared esters of dicarboxylic diterpenes and napththoquinones. 


\section{Experimental}

\subsection{General Experimental Procedures}

Optical rotations were obtained for solutions in $\mathrm{CHCl}_{3}$ (concentrations expressed in $\mathrm{g} / 100 \mathrm{~mL}$ ) on a Jasco DIP 370 polarimeter (Jasco Analytical Instruments, Easton, MD, USA). IR spectra were recorded on a Nicolet Nexus FT-IR instrument (Thermo Electron Corporation, Whaltham, MA, USA). ${ }^{1} \mathrm{H}-\mathrm{NMR}$ spectra were recorded at 400 or $500 \mathrm{MHz}$ and ${ }^{13} \mathrm{C}$-NMR data were obtained at 100 or $125 \mathrm{MHz}$ on a Bruker Avance spectrometer (Bruker, Rheinstetten, Germany). Chemical shifts are given in $\delta$ (ppm) with TMS as the internal standard. Mass spectra were measured with an EBE trisector VG Autospec Micromass spectrometer operating at $70 \mathrm{eV}$ and are presented as $m / z$ (rel. int. \%). Silica gel 60 (Merck, 63-200 $\mu \mathrm{m}$ particle size) was used for column chromatography, precoated silica gel plates (Merck, Kieselgel $60 \mathrm{~F}_{254}, 0.25 \mathrm{~mm}$ ) were used for thin layer chromatography (TLC). TLC spots were visualized by spraying the chromatograms with $p$-anisaldehyde-ethanol-acetic acid- $\mathrm{H}_{2} \mathrm{SO}_{4}$ $(2: 170: 20: 10 \mathrm{v} / \mathrm{v})$ and heating at $110{ }^{\circ} \mathrm{C}$ for $3 \mathrm{~min}$. 1,3-Dicyclohexylcarbodiimide (DCC) and dimethylaminopyridine (DMAP) were from Merck (Schuchardt, Germany).

\subsection{Plant Material}

Lapachol was isolated from the wood of Tabebuia heptaphylla as described previously [13] and purified by successive silica gel column chromatography, followed by crystallization. The diterpene junicedric acid (I) was obtained by saponification and oxidation of a mixture of labdane diterpenes from Araucaria araucana resin. The resin was collected from healthy trees in Conguillío, Araucanía Region, Chile. Voucher specimens have been deposited at the Herbarium of the Universidad de Talca.

\subsection{General Procedure for the Synthesis of Compounds I-III and V-VI}

The crude Araucaria araucana resin was worked-up as described previously $[9,10]$ to obtain a mixture of diterpenes bearing an alcohol, aldehyde, acid or ester (acetate) function at C-15 and/or C-19. After saponification ( $\mathrm{KOH}$, methanol), the diterpene mixture was oxidized with $\mathrm{CrO}_{3}$ to yield $\mathbf{I}$. Isomerization of the double bond of I to II was carried out by treating $\mathbf{I}$ in acetic acid with $47 \% \mathrm{HBr}$, stirring constantly for $24 \mathrm{~h}$. The reaction product was purified by silica gel column chromatography ( $86 \% \mathrm{w} / \mathrm{w}$ yield). Reduction of the double bond of I and IV was carried out by catalytic hydrogenation of the terpene dissolved in ethyl acetate with $10 \% \mathrm{Pd} / \mathrm{C}$ in a 1:10 molar ratio with respect to the diterpene, stirring constantly for $24 \mathrm{~h}$ to yield III and V, respectively. Compound VI was obtained by high pressure hydrogenation of compound IV.

48(9) Junicedric acid (II). $\mathrm{HBr}(3 \mathrm{~mL})$ was added to a solution of junicedric acid (I) (2.51 g, $7.47 \mathrm{mmol})$ in acetic acid (HOAc, $20 \mathrm{~mL}$ ). The mixture was stirred at room temperature for $24 \mathrm{~h}$, cooled in an ice bath, and after addition of water the aqueous phase was extracted with EtOAc $(3 \times 20 \mathrm{~mL})$. The extract was dried over anhydrous $\mathrm{Na}_{2} \mathrm{SO}_{4}$, and taken to dryness under reduced pressure. The residue was purified by silica gel column chromatography, eluting with hexane/EtOAc (8:2), yielding $2.15 \mathrm{~g}(86 \%)$ of compound II. 
17 $\beta$-Dihydrojunicedric acid (III). Junicedric acid (I) (1.10 g, $3.27 \mathrm{mmol})$ was dissolved in $30 \mathrm{~mL}$ ethyl acetate. After the addition of $\mathrm{Pd} / \mathrm{C}(10 \%)$ vacuum was made to eliminate air. Then, hydrogen $\left(\mathrm{H}_{2}\right)$ was bubbled under constant agitation for $24 \mathrm{~h}$. The reaction mixture was filtered and taken to dryness under reduced pressure. The residue was purified by silica gel column chromatography eluting with hexane/EtOAc (8:2), yielding III (827 mg, 75\%).

2-Hydroxy-3-(3-methylbutyl)-[1,4]-naphthoquinone (V). Compound V (dihydroprenyl lapachol) was synthesized from 2-hydroxy-3-(3-methyl-2-butenyl)-[1,4]-naphthoquinone (lapachol) (IV) as described for compound III, yielding $306 \mathrm{mg}(70 \%)$ of $\mathbf{V}$.

2-Hydroxy-3-(3-methyl-butyl)-5,6,7,8-tetrahydro-[1,4]-naphthoquinone (VI). A solution of lapachol (IV) (400 mg, $1.65 \mathrm{mmol})$ in HOAc (4 mL) and $\mathrm{Pd} / \mathrm{C}(10 \%)$ was submitted to a pressure of 4 bar and $65{ }^{\circ} \mathrm{C}$ for $2 \mathrm{~h}$. The reaction mixture was cooled in an ice-bath and after addition of water, the aqueous phase was extracted with EtOAc $(3 \times 20 \mathrm{~mL})$, the extracts were dried over anhydrous $\mathrm{Na}_{2} \mathrm{SO}_{4}$, and taken to dryness under reduced pressure. The residue was purified by silica gel column chromatography eluting with hexane/EtOAc (9:1), yielding dihydroprenyl-5,6,7,8-tetrahydrolapachol VI (300 mg, $73 \%)$ and $\mathbf{V}(40 \mathrm{mg}, 10 \%)$.

\subsection{General Procedure for the Synthesis of Compounds 1-12}

Compounds 1, 3, 5, 7, 9 and 11 were prepared by treating the corresponding diacids (1 mEq) in dry $\mathrm{CH}_{2} \mathrm{Cl}_{2}$ (DCM) with 1,3-dicyclohexylcarbodiimide (DCC) (1 $\left.\mathrm{mEq}\right)$ at room temperature under constant stirring. After $10 \mathrm{~min}$, lapachol or its reduction products $(1 \mathrm{mEq})$ dissolved in dry DCM, were added together with a catalytic amount of dimethylaminopyridine (DMAP). After $2-4 \mathrm{~h}$, the reaction was stopped by adding water and extracted with DCM. The extract was dried over $\mathrm{Na}_{2} \mathrm{SO}_{4}$, and purified by silica gel column chromatography, to afford compounds $\mathbf{1}, \mathbf{3}, \mathbf{5}, \mathbf{7}, \mathbf{9}$ and $\mathbf{1 1}$ in 33, 42, 35, 48, 52 and 42\% w/w yields, respectively. The corresponding methyl esters 2, 4, 6, 8, 10 and 12 were obtained treating the above cited compounds with diazomethane in $92,89,88,93,88$ and $90 \% \mathrm{w} / \mathrm{w}$ yields, respectively. The purity of all the derivatives was over $95 \%$, as determined by ${ }^{1} \mathrm{H}-\mathrm{NMR}$ spectroscopy.

Lapachoyl junicedrate (1). Junicedric acid (I) (170 mg, $0.506 \mathrm{mmol})$, DCC (104 mg, $0.506 \mathrm{mmol})$, a catalytic amount of DMAP and lapachol (IV) $(120 \mathrm{mg}, 0.506 \mathrm{mmol})$, were stirred at room temperature in dry $\mathrm{CH}_{2} \mathrm{Cl}_{2}(20 \mathrm{~mL})$ for $2-4 \mathrm{~h}$. The reaction mixture was cooled in an ice bath. After addition of water, the aqueous phase was extracted with EtOAc $(3 \times 20 \mathrm{~mL})$. The extract was dried over anhydrous $\mathrm{Na}_{2} \mathrm{SO}_{4}$ and taken to dryness under reduced pressure. The residue was purified by silica gel column chromatography, eluting with hexane/EtOAc (8:2), yielding 1 (94 mg, 33\%): brown oil; $[\alpha]_{D}^{20}$ +22 (c 0.24, $\mathrm{CHCl}_{3}$ ); IR $v_{\max }$ (film) 3398, 2928, 2840, 1768, 1692, 1672, 1641, 1445, 1286, 1170, $1075 \mathrm{~cm}^{-1} ;{ }^{1} \mathrm{H}-\mathrm{NMR}\left(\mathrm{CDCl}_{3}\right)$ : see Table $3 ;{ }^{13} \mathrm{C}-\mathrm{NMR}\left(\mathrm{CDCl}_{3}\right): 39.10$ (C-1), $19.90(\mathrm{C}-2), 37.88(\mathrm{C}-3)$, 44.18 (C-4), 56.27 (C-5), 26.02 (C-6), 38.72 (C-7), 148.01 (C-8), 56.33 (C-9), 40.88 (C-10), 21.14 (C-11), 35.86 (C-12), 31.00 (C-13), 40.58 (C-14), 170.42 (C-15), 19.96 (C-16), 106.59 (C-17), 29.07 (C-18), 178.45 (C-19), 12.79 (C-20), Quinone: 184.39, 184.52 (C-1 and C-4), 150.87 (C-2), 138.31 (C-3), 130.84, 132.00 (C-4a, C-8a), 126.73, 126.59 (C-5 and C-8), 134.88, 134.13 (C-6 and C-7), 23.67 (C-1'), 118.45 (C-2'), 133.86 (C-3'), 18.05 (C-4'), 25.85 (C-5'); EIMS m/z 560 [M] ${ }^{+}$(5), 290 (10), 244 (24), 243 (21), 
242 (100), 228 (14), 227 (85), 225 (14), 123 (10), 121 (27), 109 (13), 105 (13), 95 (10), 81 (15), 55 (13); HREIMS $m / z 560.3168$ (calcd for $\mathrm{C}_{35} \mathrm{H}_{44} \mathrm{O}_{6}, 560.3138$ ).

Table 3. Selected ${ }^{1} \mathrm{H}-\mathrm{NMR}$ data of compounds 1-6.

\begin{tabular}{|c|c|c|c|c|c|c|}
\hline $\mathrm{H}$ & 1 & 2 & 3 & 4 & 5 & 6 \\
\hline 13 & $2.10 \mathrm{~m}$ & $2.11 \mathrm{~m}$ & $2.10 \mathrm{~m}$ & $2.08 \mathrm{~m}$ & $2.05 \mathrm{~m}$ & $2.06 \mathrm{~m}$ \\
\hline $14 \alpha$ & $2.73 \mathrm{dd}$ & $2.73 \mathrm{dd}$ & $2.71 \mathrm{dd}$ & $2.71 \mathrm{dd}$ & \multirow{2}{*}{$2.65 \mathrm{dd}$} & \multirow{2}{*}{$2.66 \mathrm{dd}$} \\
\hline $14 \beta$ & $2.41-2.46 \mathrm{~m}$ & $2.42-2.47 \mathrm{~m}$ & $2.52 \mathrm{~m}$ & $2.52 \mathrm{~m}$ & & \\
\hline 16 & $1.13 \mathrm{~d}(6.6)$ & $1.13 \mathrm{~d}(6.6)$ & $1.10 \mathrm{~d}(6.6)$ & $1.10 \mathrm{~d}(6.6)$ & $1.07 \mathrm{~d}(6.6)$ & $1.08 \mathrm{~d}(6.6)$ \\
\hline 17 & $4.86 \mathrm{~s} ; 4.54 \mathrm{~s}$ & $4.87 \mathrm{~s} ; 4.54 \mathrm{~s}$ & $4.85 \mathrm{~s} ; 4.52 \mathrm{~s}$ & $4.84 \mathrm{~s} ; 4.51 \mathrm{~s}$ & $4.84 \mathrm{~s} ; 4.51 \mathrm{~s}$ & $4.86 \mathrm{~s} ; 4.51 \mathrm{~s}$ \\
\hline 18 & $1.26 \mathrm{~s}$ & $1.20 \mathrm{~s}$ & $1.23 \mathrm{~s}$ & $1.17 \mathrm{~s}$ & $1.24 \mathrm{~s}$ & $1.20 \mathrm{~s}$ \\
\hline 20 & $0.63 \mathrm{~s}$ & $0.54 \mathrm{~s}$ & $0.61 \mathrm{~s}$ & $0.51 \mathrm{~s}$ & $0.60 \mathrm{~s}$ & $0.59 \mathrm{~s}$ \\
\hline $\mathrm{OMe}$ & - & $3.64 \mathrm{~s}$ & - & $3.61 \mathrm{~s}$ & - & $3.63 \mathrm{~s}$ \\
\hline \multicolumn{7}{|c|}{ Quinone } \\
\hline 5 and 8 & $8.10 \mathrm{~m}$ & $8.10 \mathrm{~m}$ & $8.08 \mathrm{~m}$ & $8.08 \mathrm{~m}$ & $2.42 \mathrm{~m}$ & $2.44 \mathrm{~m}$ \\
\hline 6 and 7 & $7.74 \mathrm{~m}$ & $7.74 \mathrm{~m}$ & $7.71 \mathrm{~m}$ & $7.71 \mathrm{~m}$ & $1.69 \mathrm{~m}$ & $1.70 \mathrm{~m}$ \\
\hline 1 ' & 3.27 br d & $3.28 \mathrm{brd}$ & $2.41 \mathrm{~m}$ & $2.41 \mathrm{~m}$ & $2.40 \mathrm{~m}$ & $2.38 \mathrm{~m}$ \\
\hline $2^{\prime}$ & 5.07 br t & 5.09 br t & $1.34 \mathrm{~m}$ & $1.36 \mathrm{~m}$ & $1.33 \mathrm{~m}$ & $1.32 \mathrm{~m}$ \\
\hline $3^{\prime}$ & - & - & $1.59 \mathrm{~m}$ & $1.58 \mathrm{~m}$ & $1.57 \mathrm{~m}$ & $1.57 \mathrm{~m}$ \\
\hline $4^{\prime}$ & $1.77 \mathrm{~s}$ & $1.77 \mathrm{~s}$ & $0.93 \mathrm{~d}(6.6)$ & $0.93 \mathrm{~d}(6.6)$ & $0.91 \mathrm{~d}(6.6)$ & $0.92 \mathrm{~d}(6.6)$ \\
\hline 5 & $1.69 \mathrm{~s}$ & $1.69 \mathrm{~s}$ & $0.93 \mathrm{~d}(6.6)$ & $0.93 \mathrm{~d}(6.6)$ & $0.91 \mathrm{~d}(6.6)$ & $0.92 \mathrm{~d}(6.6)$ \\
\hline
\end{tabular}

Lapachoyl junicedrate methyl ester (2). Compound 1 (50 mg, $0.089 \mathrm{mmol})$, was methylated with a solution of $\mathrm{CH}_{2} \mathrm{~N}_{2}$ in ethyl ether, yielding $47 \mathrm{mg}(92 \%)$ of 2: brown oil; $[\alpha]_{D}^{20}+24\left(c 0.29, \mathrm{CHCl}_{3}\right)$; IR $v_{\max }$ (film) 2948, 2844, 1766, 1720, 1676, 1641, 1449, 1290, 1178, $1079 \mathrm{~cm}^{-1} ;{ }^{1} \mathrm{H}-\mathrm{NMR}\left(\mathrm{CDCl}_{3}\right)$ : see Table 3; ${ }^{13} \mathrm{C}-\mathrm{NMR}\left(\mathrm{CDCl}_{3}\right)$ : 39.21 (C-1), 19.94 (C-2), 38.28 (C-3), 44.33 (C-4), 56.38 (C-5), 26.28 (C-6), 38.79 (C-7), 148.11 (C-8), 56.45 (C-9), 40.87 (C-10), 21.15 (C-11), 35.90 (C-12), 30.98 (C-13), 40.39 (C-14), 170.24 (C-15), 19.99 (C-16), 106.46 (C-17), 28.84 (C-18), 177.77 (C-19), 12.59 (C-20), 51.14 (OMe), Quinone: 178.37, 184.44 (C-1 and C-4) 150.95 (C-2), 138.28 (C-3), 130.93, 132.09 (C-4a, C-8a), 126.68, 126.53 (C-5 and C-8), 134.73, 134.00 (C-6 and C-7), 23.65 (C-1'), 118.53 (C-2'), 133.74 (C-3'), 17.97 (C-4'), 25.73(C-5'); EIMS m/z 574 [M] (2), 350 (6), 291 (17), 290 (30), 258 (16), 256 (11), 243 (10), 242 (67), 227 (24), 200 (10), 180 (11), 161 (13), 159 (10), 123 (14), 122 (15), 121 (100), 109 (23), 107 (21), 105 (20), 95 (16), 93 (16), 91 (11), 81 (20), 79 (12), 67 (12), 55 (18); HREIMS $m / z 574.3308$ (calcd for $\mathrm{C}_{36} \mathrm{H}_{46} \mathrm{O}_{6}, 574.3294$ ).

Dihydroprenyl lapachoyl junicedrate (3). Compound $\mathbf{3}$ was synthesized as described for compound 1, using terpene I and quinone $\mathbf{V}$, yielding $105 \mathrm{mg}(42 \%)$ of 3: pale yellow oil; $[\alpha]_{D}^{20}+49(c) 0.14$, $\mathrm{CHCl}_{3}$ ); IR $v_{\max }$ (film) 2952, 2872, 1772, 1700, 1680, 1641, 1469, 1290, 1186, $1079 \mathrm{~cm}^{-1}$; ${ }^{1} \mathrm{H}-\mathrm{NMR}$ $\left(\mathrm{CDCl}_{3}\right)$ : see Table 3; ${ }^{13} \mathrm{C}-\mathrm{NMR}\left(\mathrm{CDCl}_{3}\right): 39.18$ (C-1), 19.97 (C-2), 37.97 (C-3), 44.24 (C-4), 56.40 (C-5), 26.07 (C-6), 38.77 (C-7), 148.01 (C-8), 56.46 (C-9), 40.61 (C-10), 21.19 (C-11), 35.93 (C-12), 31.02 (C-13), 40.89 (C-14), 170. 36 (C-15), 19.96 (C-16), 106.60 (C-17), 29.06 (C-18), 178.16 (C-19), 12.79 (C-20), Quinone: 184.10, 184.57 (C-1 and C-4) 151.14 (C-2), 140.17 (C-3), 130.96, 132.16 (C-4a, C-8a), 
126.68, 126.57 (C-5 and C-8), 134.01133 .78 (C-6 and C-7), 22.47 (C-1'), 37.51 (C-2'), 28.41 (C-3'), 22.35 (C-4'), 22.35 (C-5'); HREIMS m/z: 533.0547 [M-H-CO] ${ }^{+}$(calcd for $\mathrm{C}_{34} \mathrm{H}_{45} \mathrm{O}_{5}: 533.3267$ ).

Dihydroprenyl lapachoyl junicedrate methyl ester (4). Compound 3 (60 mg, $0.106 \mathrm{mmol}$ ) was methylated with a solution of $\mathrm{CH}_{2} \mathrm{~N}_{2}$ in ethyl ether, yielding $55 \mathrm{mg}(89 \%)$ of 4: pale yellow oil; $[\alpha]_{D}^{20}$ +62 (c 0.22, $\mathrm{CHCl}_{3}$ ); IR v $\max$ (film) 2928, 2872, 1768, 1724, 1676, 1637, 1461, 1298, 1146, 1,083 cm ${ }^{1} \mathrm{H}-\mathrm{NMR}\left(\mathrm{CDCl}_{3}\right)$ : see Table 3; ${ }^{13} \mathrm{C}-\mathrm{NMR}\left(\mathrm{CDCl}_{3}\right)$ : 39.23 (C-1), 19.97 (C-2), 37.51 (C-3), 44.35 (C-4), 56.40 (C-5), 26.29 (C-6), 38.81 (C-7), 148.11 (C-8), 56.46 (C-9), 40.41 (C-10), 21.19 (C-11), 35.93 (C-12), 31.02 (C-13), 40.89 (C-14), 170. 36 (C-15), 20.01 (C-16), 106.50 (C-17), 28.87 (C-18), 178.16 (C-19), 12.61 (C-20), 51.17 (OMe), Quinone: 184.10, 184.57 (C-1 and C-4) 151.11 (C-2), 140.17 (C-3), 130.96, 132.16 (C-4a, C-8a), 126.68, 126.56 (C-5 and C-8), 134.02, 133.78 (C-6 and C-7), 22.47 (C-1'), 37.51 (C-2'), $28.41\left(\mathrm{C}-3^{\prime}\right), 22.35\left(\mathrm{C}-4^{\prime}\right), 22.35\left(\mathrm{C}-5^{\prime}\right)$; HREIMS $m / z: 577.1957[\mathrm{M}+\mathrm{H}]^{+}$(calc for $\mathrm{C}_{36} \mathrm{H}_{49} \mathrm{O}_{6}$, 577.3529).

Dihydroprenyl-5, 6, 7,8-tetrahydrolapachoyl junicedrate (5). Compound 5 was synthesized as described for compound 1, using terpene I and quinone VI, yielding $87 \mathrm{mg}(35 \%)$ of 5: pale yellow oil; $[\alpha]_{D}^{20}+35$ (c $0.55, \mathrm{CHCl}_{3}$ ); IR $v_{\max }$ (film) 3338, 2924, 2860, 1768, 1692, 1661, 1621, 1473, 1206, 1134, $1083 \mathrm{~cm}^{-1}$; ${ }^{1} \mathrm{H}-\mathrm{NMR}\left(\mathrm{CDCl}_{3}\right)$ : see Table 3; ${ }^{13} \mathrm{C}-\mathrm{NMR}\left(\mathrm{CDCl}_{3}\right)$ : 39.10 (C-1), 19.88 (C-2), 37.89 (C-3), 44.17 (C-4), 56.33 (C-5), 26.00 (C-6), 38.71 (C-7), 147.93 (C-8), 56.38 (C-9), 40.54 (C-10), 21.03 (C-11), 35.84 (C-12), 30.94 (C-13), 40.77 (C-14), 170.46 (C-15), 19.88 (C-16), 106.53 (C-17), 28.99 (C-18), 180.25 (C-19), 12.70 (C-20), Quinone: 184.24, 186.91 (C-1 and C-4) 148.60 (C-2), 140.85 (C-3), 136.89, 142.76 (C-4a, C-8a), 22.30, 21.03 (C-5 and C-8), 21.85, 21.11 (C-6 and C-7), 22.79 (C-1'), 37.46 (C-2'), 28.23 (C-3'), 22.26 (C-4'), 22.26 (C-5'); EIMS m/z 566 [M] ${ }^{+}$(2), 273 (12), 251 (17), 250 (100), 248 (15), 193 (11), 192 (21), 121 (12). HREIMS $m / z 566.3633$ (calcd for $\mathrm{C}_{35} \mathrm{H}_{50} \mathrm{O}_{6}, 566.3607$ ).

Dihydroprenyl-5,6,7,8-tetrahydrolapachoyl junicedrate methyl ester (6). Compound 5 (40 mg, $0.071 \mathrm{mmol}$ ) was methylated with a solution of $\mathrm{CH}_{2} \mathrm{~N}_{2}$ in ethyl ether, yielding $36 \mathrm{mg}(88 \%)$ of 6: pale yellow oil, $[\alpha]_{D}^{20}+28\left(c 0.20, \mathrm{CHCl}_{3}\right)$; IR $v_{\max }$ (film) 2948, 2872, 1764, 1720, 1661, 1621, 1457, 1214, 1134, $1083 \mathrm{~cm}^{-1} ;{ }^{1} \mathrm{H}-\mathrm{NMR}\left(\mathrm{CDCl}_{3}\right)$ : see Table 3; ${ }^{13} \mathrm{C}-\mathrm{NMR}\left(\mathrm{CDCl}_{3}\right)$ : $39.43(\mathrm{C}-1), 20.12(\mathrm{C}-2), 38.50(\mathrm{C}-3)$, 44.55 (C-4), 56.61 (C-5), 26.49 (C-6), 39.01 (C-7), 148.32 (C-8), 56.66 (C-9), 40.60 (C-10), 22.11 (C-11), 36.13 (C-12), 31.20 (C-13), 41.04 (C-14), 170.69 (C-15), 20.21 (C-16), 106.66 (C-17), 29.06 (C-18), 177.98 (C-19), 12.79 (C-20), 51.34 (OMe), Quinone: 180.52, 187.19 (C-1 and C-4) 148.86 (C-2), 141.11 (C-3), 137.15, 143.02 (C-4a, C- 8a), 23.04, 22.49 (C-5 and C-8), 21.28, 21.28 (C-6 and C-7), 21.37 (C-1'), 37.71 (C-2'), 28.49 (C-3'), 22.48 (C-4'), 22.48 (C-5'); EIMS m/z 580 [M] ${ }^{+}$(2), 333 (13), 273 (19), 251 (17), 250 (100), 121 (22); HREIMS $m / z 580.3844$ (calcd for $\mathrm{C}_{36} \mathrm{H}_{52} \mathrm{O}_{6}, 580.3764$ ).

Lapachoyl 48(9) junicedrate (7). Compound 7 was synthesized as described for compound $\mathbf{1}$, using diterpene II and quinone IV, yielding $124 \mathrm{mg}(48 \%)$ of 7: pale yellow oil; $[\alpha]_{D}^{20}+72\left(c 0.15, \mathrm{CHCl}_{3}\right)$; IR $v_{\max }$ (film) 3378, 2932, 2864, 1772, 1728, 1692, 1684, 1461, 1294, 1170, $1071 \mathrm{~cm}^{-1}$; ${ }^{1} \mathrm{H}-\mathrm{NMR}$ $\left(\mathrm{CDCl}_{3}\right)$ : see Table 4; ${ }^{13} \mathrm{C}-\mathrm{NMR}\left(\mathrm{CDCl}_{3}\right): 37.21(\mathrm{C}-1), 19.52(\mathrm{C}-2), 37.44(\mathrm{C}-3), 43.78(\mathrm{C}-4), 53.55$ (C-5), 20.73 (C-6), 34.26 (C-7), 126.82 (C-8), 139.89 (C-9), 39.76 (C-10), 25.65 (C-11), 34.20 (C-12), 31.35 (C-13), 41.03 (C-14), 170.19 (C-15), 19.72 (C-16), 19.61 (C-17), 28.65 (C-18), 183.77 (C-19), 17.97 (C-20), Quinone: 178.35, 184.50 (C-1 and C-4) 150.96 (C-2), 138.28 (C-3), 130.93, 132.09 (C-4a, 
C-8a), 126.69, 126.53 (C-5 and C-8), 134.74, 134.01 (C-6 and C-7), 23.65 (C-1'), 118.51 (C-2'), 133.76 (C-3'), 17.97 (C-4'), 25.73 (C-5'); EIMS m/z 560 [M] (3), 244 (45), 243 (14), 242 (73), 228 (16), 227 (100), 225 (14), 221 (31), 175 (17), 173 (13), 109 (11), 105 (16), 95 (10), 81 (11), 55 (14); HREIMS $m / z 560.3135$ (calcd for $\mathrm{C}_{35} \mathrm{H}_{44} \mathrm{O}_{6}, 560.3138$ ).

Table 4. Selected ${ }^{1} \mathrm{H}-\mathrm{NMR}$ Data of compounds 7-12.

\begin{tabular}{|c|c|c|c|c|c|c|}
\hline $\mathrm{H}$ & 7 & 8 & 9 & 10 & 11 & 12 \\
\hline 13 & $2.12 \mathrm{~m}$ & $2.12 \mathrm{~m}$ & $2.10 \mathrm{~m}$ & $2.10 \mathrm{~m}$ & $2.12 \mathrm{~m}$ & $2.11 \mathrm{~m}$ \\
\hline $14 \alpha$ & $2.72 \mathrm{dd}$ & $2.72 \mathrm{dd}$ & $2.72 \mathrm{dd}$ & $2.70 \mathrm{dd}$ & $2.74 \mathrm{dd}$ & $2.72 \mathrm{dd}$ \\
\hline $14 \beta$ & $2.50 \mathrm{dd}$ & $2.50 \mathrm{dd}$ & $2.53 \mathrm{~m}$ & $2.53 \mathrm{~m}$ & $2.46 \mathrm{dd}$ & $2.45 \mathrm{dd}$ \\
\hline 16 & $1.15 \mathrm{~d}(6.6)$ & $1.15 \mathrm{~d}(6.5)$ & $1.12 \mathrm{~d}(6.6)$ & $1.12 \mathrm{~d}(6.6)$ & $1.15 \mathrm{~d}(6.6)$ & $1.14 \mathrm{~d}(6.6)$ \\
\hline 17 & $1.54 \mathrm{~s}$ & $1.62 \mathrm{~s}$ & $1.59 \mathrm{~s}$ & $1.59 \mathrm{~s}$ & $0.95 \mathrm{~d}(7.5)$ & $0.93 \mathrm{~d}(7.5)$ \\
\hline 18 & $1.28 \mathrm{~s}$ & $1.22 \mathrm{~s}$ & $1.25 \mathrm{~s}$ & $1.19 \mathrm{~s}$ & $1.27 \mathrm{~s}$ & $1.19 \mathrm{~s}$ \\
\hline 20 & $0.91 \mathrm{~s}$ & $0.80 \mathrm{~s}$ & $0.88 \mathrm{~s}$ & $0.77 \mathrm{~s}$ & $0.83 \mathrm{~s}$ & $0.70 \mathrm{~s}$ \\
\hline $\mathrm{OMe}$ & - & $3.65 \mathrm{~s}$ & - & $3.62 \mathrm{~s}$ & - & $3.66 \mathrm{~s}$ \\
\hline \multicolumn{7}{|c|}{ Quinone } \\
\hline 5 and 8 & $8.11 \mathrm{~m}$ & $8.11 \mathrm{~m}$ & $8.09 \mathrm{~m}$ & $8.09 \mathrm{~m}$ & $8.10 \mathrm{~m}$ & $8.10 \mathrm{~m}$ \\
\hline 6 and 7 & $7.75 \mathrm{~m}$ & $7.75 \mathrm{~m}$ & $7.72 \mathrm{~m}$ & $7.72 \mathrm{~m}$ & $7.74 \mathrm{~m}$ & $7.74 \mathrm{~m}$ \\
\hline 1 ' & 3.29 br d & $3.28 \mathrm{br} \mathrm{d}$ & $2.46 \mathrm{~m}$ & $2.46 \mathrm{~m}$ & $3.28 \mathrm{brd}$ & 3.28 br d \\
\hline $2^{\prime}$ & 5.09 br t & 5.09 br t & $1.35 \mathrm{~m}$ & $1.36 \mathrm{~m}$ & 5.08 br t & 5.09 br t \\
\hline 3, & - & - & $1.58 \mathrm{~m}$ & $1.58 \mathrm{~m}$ & - & - \\
\hline $4^{\prime}$ & $1.78 \mathrm{~s}$ & 1.78 br s & $0.93 \mathrm{~d}(6.6)$ & $0.93 \mathrm{~d}(6.6)$ & $1.78 \mathrm{br} \mathrm{s}$ & 1.78 br s \\
\hline 5 & $1.70 \mathrm{~s}$ & $1.70 \mathrm{br} \mathrm{s}$ & $0.93 \mathrm{~d}(6.6)$ & $0.93 \mathrm{~d}(6.6)$ & $1.70 \mathrm{br} \mathrm{s}$ & $1.69 \mathrm{br} \mathrm{s}$ \\
\hline
\end{tabular}

Lapachoyl 48(9) junicedrate methyl ester (8). Compound 7 (60 mg, $0.107 \mathrm{mmol})$ was methylated with a solution of $\mathrm{CH}_{2} \mathrm{~N}_{2}$ in ethyl ether, yielding $57 \mathrm{mg}(93 \%)$ of 8: pale yellow oil; $[\alpha]_{D}^{20}+57(c 0.10$, $\mathrm{CHCl}_{3}$ ); IR $v_{\max }$ (film) 2924, 2876, 1768, 1720, 1688, 1637, 1461, 1290, 1138, $1075 \mathrm{~cm}^{-1}$; ${ }^{1} \mathrm{H}-\mathrm{NMR}$ $\left(\mathrm{CDCl}_{3}\right)$ : see Table 4; ${ }^{13} \mathrm{C}-\mathrm{NMR}\left(\mathrm{CDCl}_{3}\right): 37.28$ (C-1), 19.52 (C-2), $37.76(\mathrm{C}-3), 43.91$ (C-4), 53.58 (C-5), 20.87 (C-6), 34.34 (C-7), 126.80 (C-8), 139.86 (C-9), 39.59 (C-10), 25.73 (C-11), 34.24 (C-12), 31.35 (C-13), 41.03 (C-14), 170.21 (C-15), 19.74 (C-16), 19.61 (C-17), 28.47 (C-18), 178.12 (C-19), 17.79 (C-20), 51.08 (OMe), Quinone: 178.37, 184.76 (C-1 and C-4) 150.94 (C-2), 138.24 (C-3), 130.93, 132.11 (C-4a, C-8a), 126.69, 126.53 (C-5 and C-8), 134.74, 134.01 (C-6 and C-7), 23.65 (C-1'), 118.52 (C-2'), 133.75 (C-3'), 17.97 (C-4'), 25.73 (C-5'); EIMS m/z 574 [M] (5), 256 (15), 245 (15), 244 (91), 243 (23), 242 (100), 235 (25), 227 (52), 175 (25), 173 (22), 121 (13), 107 (11), 105 (12), 55 (11); HREIMS $m / z 574.3307$ (calcd for $\mathrm{C}_{36} \mathrm{H}_{46} \mathrm{O}_{6}, 574.3294$ ).

Dihydroprenyl lapachoyl $48(9)$ junicedrate (9). Compound 9 was synthesized as described for compound 1, using terpene II and quinone $\mathbf{V}$, yielding $91 \mathrm{mg}(52 \%)$ of 9: pale yellow oil; $[\alpha]_{D}^{20}+41$ (c $0.18, \mathrm{CHCl}_{3}$ ); IR (film) $v_{\max } 2936,2876,1768,1696,1680,1637,1465,1294,1150,1079 \mathrm{~cm}^{-1}$; ${ }^{1} \mathrm{H}-\mathrm{NMR}\left(\mathrm{CDCl}_{3}\right)$ : see Table 4; ${ }^{13} \mathrm{C}-\mathrm{NMR}\left(\mathrm{CDCl}_{3}\right)$ : 37.25 (C-1), 19.55 (C-2), 37.51 (C-3), 43.79 (C-4), 53.55 (C-5), 20.76 (C-6), 34.27 (C-7), 126.84 (C-8), 140.18 (C-9), 39.78 (C-10), 25.78 (C-11), 34.20 (C-12), 31.41 (C-13), 41.06 (C-14), 170.32 (C-15), 19.75 (C-16), 19.56 (C-17), 28.68 (C-18), 178.17 (C-19), 17.98 (C-20), Quinone; 183.70, 184.58 (C-1 and C-4) 151.11 (C-2), 139.02 (C-3), 130.97, 
132.17 (C-4a, C-8a), 126.69, 126.57 (C-5 and C-8), 134.04, 133.80 (C-6 and C-7), 22.47 (C-1'), 37.51

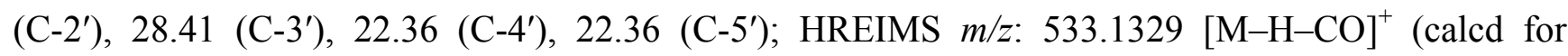
$\mathrm{C}_{34} \mathrm{H}_{45} \mathrm{O}_{5}:$ 533.3267).

Dihydroprenyl lapachoyl $\Delta 8(9)$ junicedrate methyl ester (10). Compound 9 (40 mg, $0.071 \mathrm{mmol}$ ), was methylated with a solution of $\mathrm{CH}_{2} \mathrm{~N}_{2}$ in ethyl ether, yielding $36 \mathrm{mg}(88 \%)$ of 10: pale yellow oil; $[\alpha]_{D}^{20}$ +39 (c 0.24, $\mathrm{CHCl}_{3}$ ); IR (film) $v_{\max } 2928,2876,1768,1724,1668,1637,1461,1290,1154,1071 \mathrm{~cm}^{-1}$; ${ }^{1} \mathrm{H}-\mathrm{NMR}\left(\mathrm{CDCl}_{3}\right)$ : see Table 4; ${ }^{13} \mathrm{C}-\mathrm{NMR}\left(\mathrm{CDCl}_{3}\right): 37.30(\mathrm{C}-1), 19.57$ (C-2), 37.51 (C-3), $43.92(\mathrm{C}-4)$, 53.59 (C-5), 20.89 (C-6), 34.36 (C-7), 126.83 (C-8), 139.08 (C-9), 39.60 (C-10), 25.77 (C-11), 34.24 (C-12), 31.41 (C-13), 41.06 (C-14), 170.31 (C-15), 19.77 (C-16), 19.62 (C-17), 28.49 (C-18), 178.15 (C-19), 17.80 (C-20), 51.14 (OMe), Quinone: 183.67, 184.50 (C-1 and C-4) 151.11 (C-2), 139.08 (C-3), 130.97, 132.17 (C-4a, C-8a), 126.69, 126.57 (C-5 and C-8), 134.03, 133.79 (C-6 and C-7), 22.46 (C-1'), $37.51\left(\mathrm{C}-2^{\prime}\right), 28.41\left(\mathrm{C}-3^{\prime}\right), 22.36\left(\mathrm{C}-4^{\prime}\right), 22.36\left(\mathrm{C}-5^{\prime}\right)$; HREIMS $m / z: 577.1957[\mathrm{M}+\mathrm{H}]^{+}$(calcd for $^{2}$ $\left.\mathrm{C}_{36} \mathrm{H}_{49} \mathrm{O}_{6}: 577.3529\right)$.

Lapachoyl 17ß-dihydrojunicedrate (11). Compound 11 was prepared as described for compound 1, from diterpene III and quinone IV, yielding $85 \mathrm{mg}(42 \%)$ of 11: brown oil; $[\alpha]_{D}^{20}+20\left(c 0.09, \mathrm{CHCl}_{3}\right)$; IR (film) $v_{\max } 3398,2956,2848,1772,1692,1676,1637,1457,1290,1170,1075 \mathrm{~cm}^{-1}$; ${ }^{1} \mathrm{H}-\mathrm{NMR}$ $\left(\mathrm{CDCl}_{3}\right)$ : see Table 4; ${ }^{13} \mathrm{C}-\mathrm{NMR}\left(\mathrm{CDCl}_{3}\right): 39.83$ (C-1), 19.01 (C-2), 37.96 (C-3), 43.82 (C-4), 53.06 (C-5), 23.07 (C-6), 35.00 (C-7), 29.35 (C-8), 57.50 (C-9), 39.74 (C-10), 18.85 (C-11), 35.23 (C-12), 30.88 (C-13), 40.84 (C-14), 170.32 (C-15), 20.15 (C-16), 15.00 (C-17), 29.04 (C-18), 182.00 (C-19), 14.43 (C-20), Quinone: 178.42, 184.48 (C-1 and C-4) 150.98 (C-2), 138.32 (C-3), 130.97, 132.13 (C-4a, C-8a), 126.71, 126.57 (C-5 and C-8), 133.78, 134.04 (C-6 and C-7), 23.68 (C-1'), 118.55 (C-2'), 134.78 (C-3'), 17.99 (C-4'), 25.76 (C-5'); EIMS m/z $562\left[\right.$ [M] $^{+}$(5), 500 (20), 374 (10), 244 (43), 243 (18), 242 (100), 227 (64), 221 (16), 168 (15), 141 (16), 123 (15), 109 (18), 95 (13), 83 (12), 81 (14), 55 (19); HREIMS $m / z 562.3280$ (calcd for $\mathrm{C}_{35} \mathrm{H}_{46} \mathrm{O}_{6}, 562.3294$ ).

Lapachoyl 17ß-dihydrojunicedrate methyl ester (12). Compound 11 (40 mg, $0.071 \mathrm{mmol}$ ) was methylated with a solution of $\mathrm{CH}_{2} \mathrm{~N}_{2}$ in ethyl ether, yielding $37 \mathrm{mg}(90 \%)$ of 12: brown oil; $[\alpha]_{D}^{20}+24$ (c 0.34, $\mathrm{CHCl}_{3}$ ); IR (film) $v_{\max } 2944,2844,1764,1724,1676,1637,1457,1290,1146,1079 \mathrm{~cm}^{-1}$; ${ }^{1} \mathrm{H}-\mathrm{NMR}\left(\mathrm{CDCl}_{3}\right)$ : see Table 4; ${ }^{13} \mathrm{C}-\mathrm{NMR}\left(\mathrm{CDCl}_{3}\right)$ : 39.85 (C-1), 19.09 (C-2), 37.27 (C-3), 43.93 (C-4), 52.99 (C-5), 23.06 (C-6), 34.98 (C-7), 29.30 (C-8),57.52 (C-9), 38.71 (C-10), 18.89 (C-11), 35.26 (C-12), 30.87 (C-13), 40.81 (C-14), 170.26 (C-15), 20.15 (C-16), 14.95 (C-17), 28.86 (C-18), 178.07 (C-19), 14.95 (C-20), 51.11 (OMe), Quinone: 178.36, 184.41 (C-1 and C-4) 150.95 (C-2), 138.27 (C-3), 130.93, 132.09 (C-4a, C-8a), 126.68, 126.53 (C-5 and C-8), 134.74, 134.00 (C-6 and C-7), 23.66 (C-1'), 118.53 (C-2'), 133.74 (C-3'), 17.98 (C-4'), 25.74 (C-5'); EIMS m/z 576 [M] (2), 293 (17), 244 (20), 243 (20), 242 (100), 227 (27), 123 (28), 109 (14), 95 (10), 81 (11), 55 (11); HREIMS m/z 576.3580 (calcd for $\left.\mathrm{C}_{36} \mathrm{H}_{48} \mathrm{O}_{6}, 576.3451\right)$.

\subsection{HCl-EtOH-Induced Ulcer Model in Mice [7-10,27]}

The gastroprotective activity of the compounds was assessed in the EtOH-HCl-induced gastric lesion model. Male Swiss albino mice weighing $30 \pm 3 \mathrm{~g}$ were used. The animals were fed on certified 
Champion diet with free access to water under standard conditions of $12 \mathrm{~h}$ dark-light period, $50 \%$ relative humidity, and $22{ }^{\circ} \mathrm{C}$ room temperature. The mice were randomly distributed into groups of 7-14 animals each and fasted for $24 \mathrm{~h}$ with free access to water before the oral administration of test samples by gavage. The purity of the tested compounds was higher than $95 \%$ by NMR analysis. To keep the animal numbers to a minimum, dose-response studies were performed with lapachol at 5, 10 and $50 \mathrm{mg} / \mathrm{kg}$ to set the conditions for single-dose comparison of gastroprotective effect. The tested compounds, lansoprazole $(20 \mathrm{mg} / \mathrm{kg})$ or the vehicle $(12 \%$ Tween $80,10 \mathrm{~mL} / \mathrm{kg})$ were administered orally by gavage. After $50 \mathrm{~min}$, all groups were orally treated with $0.2 \mathrm{~mL}$ of a solution containing $60 \% \mathrm{EtOH}-0.3 \mathrm{M} \mathrm{HCl}$ for gastric lesion induction. Animals were sacrificed by cervical dislocation $1 \mathrm{~h}$ after the administration of EtOH-HCl, and the stomachs excised and inflated by injection of 5\% formalin $(1 \mathrm{~mL})$. The ulcerated stomachs were fixed in 5\% formalin for $30 \mathrm{~min}$ and opened along the greater curvature. The length $(\mathrm{mm})$ of each lesion was measured, and the lesion index expressed as the sum of the length of all lesions. Based on previous studies on the parent diterpenes, comparison of the new compounds 1-12 was carried out at a single oral dose of $5 \mathrm{mg} / \mathrm{kg}$. The protocols were approved by the Universidad de Talca Institutional Animal Care and Use Committee, which follows the recommendations of the Canadian Council on Animal Care. Tween 80 and lansoprazole ( $>98 \%$ purity by HPLC) were purchased from Sigma-Aldrich.

\subsection{Cytotoxicity Assay [28]}

The human cell lines MRC-5 normal lung fibroblasts (ATCC CCL-171), AGS gastric adenocarcinoma cells (ATCC CRL-1739), and Hep G2 hepatocellular carcinoma cells (ATCC HB-8065) were obtained from the American Type Culture Collection (ATCC, Manassas, VA, USA). The cells were grown as monolayers in the following media: MRC-5 and Hep G2 in minimum essential Eagle's medium (MEM), with Earle's salts, $2.0 \mathrm{mM}$ L-glutamine (Sigma Chemical Co.) and $2.2 \mathrm{~g} / \mathrm{L}$ sodium bicarbonate (Sigma Chemical Co.), supplemented with 10\% heat-inactivated fetal bovine serum (FBS), $100 \mathrm{IU} / \mathrm{mL}$ penicillin, and $100 \mu \mathrm{g} / \mathrm{mL}$ streptomycin in a humidified incubator with $5 \% \mathrm{CO}_{2}$ in air at $37{ }^{\circ} \mathrm{C}$. Cell passage was maintained between 10 and 16 for MRC-5 and between 79 and 82 for Hep G2 cells. The medium was changed every 2 days. Culture media, antibiotics, and FBS were obtained from Invitrogen Corp. Human gastric adenocarcinoma cells AGS (ATCC CRL-1739) were grown as monolayers in Ham F-12 medium containing $1.0 \mathrm{mM}$ L-glutamine and $1.5 \mathrm{~g} / \mathrm{L}$ sodium bicarbonate, supplemented with $10 \%$ heat-inactivated FBS, $100 \mathrm{IU} / \mathrm{mL}$ penicillin, and $100 \mu \mathrm{g} / \mathrm{mL}$ streptomycin in a humidified incubator with $5 \% \mathrm{CO}_{2}$ in air at $37^{\circ} \mathrm{C}$. Cell passage was maintained between 42 and 48 . The medium was changed every 2 days.

Confluent cultures of the different cell lines were treated with medium containing the compounds at concentrations ranging from 1 up to $1,000 \mu \mathrm{M}$. The antisecretory drug lansoprazole was used as reference compound. The substances were first dissolved in DMSO and then in the corresponding culture medium supplemented with $2 \%$ FBS. The final concentration of DMSO in the test medium and controls was $1 \%$. The cells were exposed for $24 \mathrm{~h}$ to test medium with or without the compound (control). Each concentration was tested in quadruplicate together with the control and repeated three times in separate experiments. At the end of the incubation the neutral red uptake assay was performed. 


\subsection{Statistical Analysis}

Results were expressed as the mean \pm SEM. In all experiments, statistical differences between several treatments and their respective control were determined by one-way ANOVA with StudentNewman-Keuls post-hoc test. The level of significance was set at $\mathrm{P}<0.05$.

\section{Conclusions}

The aim of this work was to synthesize diterpenylnaphthoquinones combining diterpene and quinone moieties. To determine structure-activity relationships/trends, 12 esters were prepared. The diterpenes used as building blocks comprised the diacids I, II and III. The naphthoquinone moieties included lapachol, dihydroprenyl lapachol, and dihydroprenyl-5,6,7,8-tetrahydrolapachol. Compounds $\mathbf{6 , 8}$ and 10 were significantly active as antiulcer agents, protecting against induced gastric lesions in mice by 74,84 and $76 \%$, respectively. Basal cytotoxicity of the compounds was determined on the following human cell lines: normal lung fibroblasts (MRC-5), gastric epithelial adenocarcinoma (AGS) and hepatocellular carcinoma (Hep G2). Some compounds showed selective cytotoxicity against AGS cells. Derivative 5 was the most cytotoxic product, with $\mathrm{IC}_{50}$ values of 69,40 and $27 \mu \mathrm{M}$ for fibroblasts, AGS and Hep G2 cells, respectively. Derivative 6, with strong gastroprotective activity, was devoid of cytotoxic effect towards the selected cell lines. The new compounds had different biological effects than the building blocks and some of them were less toxic than the starting molecules.

\section{Acknowledgments}

Financial support of this work under FONDECYT Project 1085306 and Programa de Investigación en Productos Bioactivos, Universidad de Talca is gratefully acknowledged. M.W.P. thanks the PBCT PSD50 for a postdoctoral grant. The skillful technical work of Irene Manriquez is gratefully acknowledged.

\section{Conflict of Interest}

The authors declare no conflict of interest.

\section{References and Notes}

1. WHO. The World Health Report; WHO: Geneva, Switzerland, 2003; p. 154-159.

2 Bahmanyar, S.; Ye, W.; Dickman, P.W.; Nyren, O. Long-term risk of gastric cancer by subsite in operated and unoperated patients hospitalized for peptic ulcer. Am. J. Gastroenterol. 2007, 102, 1185-1191.

3. Luo, J.; Nordenvall, C.; Nyren, O.; Adami, H.O.; Permert, J.; Ye, W. The risk of pancreatic cancer in patients with gastric or duodenal ulcer disease. Int. J. Cancer 2007, 120, 368-372.

4 Areche, C.; Rodríguez, J.A.; Razmilic, I.; Yañez, T.; Theoduloz, C.; Schmeda-Hirschmann, G. Gastroprotective and cytotoxic effect of semisynthetic ferruginol derivatives. J. Pharm. Pharmacol. 2007, 59, 289-300. 
5 Pertino, M.; Schmeda-Hirschmann, G.; Rodríguez, J.; Theoduloz, C. Gastroprotective effect and cytotoxicity of terpenes from the Paraguayan crude drug "yagua rova" (Jatropha isabelli). J. Ethnopharmacol. 2007, 111, 553-559.

6. Rodríguez, J.; Theoduloz, C.; Yáñez, T.; Becerra, J.; Schmeda-Hirschmann, G. Gastroprotective and ulcer healing effect of ferruginol in mice and rats: Assessment of its mechanism of action using in vitro models. Life Sci. 2005, 78, 2503-2509.

7. Rodríguez, J.A.; Theoduloz, C.; Sánchez, M.; Razmilic, I.; Schmeda-Hirschmann, G. Gastroprotective and ulcer-healing effect of new solidagenone derivatives in human cell cultures. Life Sci. 2005, 77, 2193-2205.

8. Schmeda-Hirschmann, G.; Rodríguez, J.A.; Astudillo, L. Gastroprotective activity of the diterpene solidagenone and its derivatives on experimentally induced gastric lesions in mice. J. Ethnopharmacol. 2002, 81, 111-115.

9. Schmeda-Hirschmann, G.; Astudillo, L.; Sepúlveda, B.; Rodríguez, J.; Theoduloz, C.; Yáñez, T.; Palenzuela, J.A. Gastroprotective effect and cytotoxicity of natural and semisynthetic labdane diterpenes from Araucaria araucana resin. Z. Naturforsch. C 2005, 60, 511-522.

10. Schmeda-Hirschmann, G.; Astudillo, L.; Rodríguez, J.; Theoduloz, C.; Yáñez, T. Gastroprotective effect of the Mapuche crude drug Araucaria araucana resin and its main constituents. J. Ethnopharmacol. 2005, 101, 271-276.

11. Sepúlveda, B.; Astudillo, L.; Rodríguez, J.; Yáñez, T.; Theoduloz, C.; Schmeda-Hirschmann, G. Gastroprotective and cytotoxic effect of dehydroabietic acid derivatives. Pharmacol. Res. 2005, 52, 429-437.

12. Halle, W.; Spielmann, H. Two procedures for the prediction of acute toxicity (LD50) from cytotoxicity data. ATLA 1992, 20, 40-49.

13. Schmeda Hirschmann, G.; Papastergiou, F. Naphthoquinone derivatives and lignans from the Paraguayan crude drug "tayï pytá" (Tabebuia heptaphylla, Bignoniaceae). Z. Naturforsch. C 2003, 58, 495-501.

14. Pérez, S.; Estevez-Braun, E.; Ravelo, A.; Ferro, A.G.; Tokuda, E.A.; Mukainaka, H.; Nishino, T. Inhibitory effects of lapachol derivatives on Epstein-Barr virus activation. Bioorg. Med. Chem. 2003, 11, 483-488.

15. Barbosa, T.P.; Câmara, C.A.; Silva, T.M.S.; Martins, R.M.; Pinto, A.C.; Vargas, M.D. New 1,2,3,4-tetrahydro-1-aza-anthraquinones and 2-aminoalkyl compounds from norlapachol with molluscicidal activity. Bioorg. Med. Chem. 2005, 13, 6464-6469.

16. Silva, T.M.S.; Camara, C.A.; Barbosa, T.P.; Soares, A.Z.; da Cunha, L.C.; Pinto, A.C.; Vargas, M.D. Molluscicidal activity of synthetic lapachol amino and hydrogenated derivatives. Bioorg. Med. Chem. 2005, 13, 193-196.

17. Silva, R.S.F.; Costa, E.M.; Trindade, U.L.T.; Teixeira, D.V.; Pinto, M de C. F.R.; Santos, G.L.; Malta, V.R.S.; De Simone, C.A.; Pinto, A.V.; de Castro, S.L. Synthesis of naphthofuranquinones with activity against Trypanosoma cruzi. Eur. J. Med. Chem. 2006, 41, 526-530.

18. da Silva, A.J.M.; Buarque, C.D.; Brito, F.V.; Aurelian, L.; Macedo, L.F.; Malkas, L.H.; Hickey, R.J.; Lopes, D.V.S.; Noel, F.; Murakami, Y.L.B.; et al. Synthesis and preliminary pharmacological evaluation of new (+/-) 1,4-naphthoquinones structurally related to lapachol. Bioorg. Med. Chem. 2002, 10, 2731-2738. 
19. Esteves-Souza, A.; Figueiredo, D.V.; Esteves, A.; Câmara, C.A.; Vargas, M.D.; Pinto, A.C.; Echevarría, A. Cytotoxic and DNA-topoisomerase effects of lapachol amine derivatives and interactions with DNA. Braz. J. Med. Biol. Res. 2007, 40, 1399-1402.

20. Muregi, F.W.; Ishih, A. Next-generation antimalarial drugs: Hybrid molecules as a new strategy in drug design. Drug Devel. Res. 2010, 71, 20-32.

21. Morphy, R.; Rankovic, Z. Designed multiple ligands. An emerging drug discovery paradigm. J. Med. Chem. 2005, 48, 6523-6543.

22. Morphy, R.; Rankovic, Z. Fragments, network biology and designing multiple ligands. Drug Discov. Today 2007, 12, 156-160.

23. Morphy, R.; Rankovic, Z. Multi-target drugs: Strategies and challenges for medicinal chemists. The Practice of Medicinal Chemistry, 3rd ed.; Wermuth, C.G., Ed.; Elsevier-Academic Press: San Diego, CA, USA, 2008; pp. 549-571.

24. Schmeda-Hirschmann, G.; Pertino, M.; Rodriguez, J.A.; Monsalve, F.; Droguett, D.; Theoduloz, C. Synthesis, gastroprotective effect and cytotoxicity of new amino acid diterpene monoamides and diamides. Molecules 2010, 15, 7378-7394.

25. del Corral, J.M.M.; Castro, M.A.; Rodríguez, M.L.; Chamorro, P.; Cuevas, C.; San Feliciano, A. New cytotoxic diterpenylnaphthohydroquinone derivatives obtained from a natural diterpenoid. Bioorg. Med. Chem. 2007, 15, 5760-5774.

26. Molinari, A.; Oliva, A.; Ojeda, C.; Escobar, J.; Gallardo, C.; del Corral, J.M.; Castro M.A.; Cuevas, C.; San Feliciano, A. Synthesis, characterisation and cytotoxicity of chloro derivatives of prenylnaphthohydroquinone. Bioorg. Med. Chem. 2005, 13, 3841-3846.

27. Olfert, E.D.; Cross, B.M.; McWilliam, A.A. Guide to the Care and Use of Experimental Animals; Canadian Council on Animal Care: Ottawa, Ontario, Canada, 1993; Volume 1, pp. 1-213.

28. Rodríguez, J.A.; Haun, M. Cytotoxicity of trans-dehydrocrotonin from Croton cajucara on V79 cells and rat hepatocytes. Planta Med. 1999, 65, 522-526.

Sample Availability: Samples of the compounds lapachol, junicedric acid and some derivatives are available from the authors.

(C) 2011 by the authors; licensee MDPI, Basel, Switzerland. This article is an open access article distributed under the terms and conditions of the Creative Commons Attribution license (http://creativecommons.org/licenses/by/3.0/). 